\title{
APPLICATION OF GEOARCHAEOLOGICAL EVOLUTIONARY MODELS FOR THE INTERPRETATION OF COMPLEX ARCHAEOLOGICAL STRUCTURES IN THE CENTRAL EBRO BASIN (SPAIN)
}

J.L. Peña-Monné ${ }^{1}$, M.M. Sampietro-Vattuone ${ }^{2 *}$, J. V.Picazo ${ }^{3}$, L.A. Longares ${ }^{1}$, F. Pérez-Lambán ${ }^{4}$, D. Badia 5 ${ }^{1}$ Dpto. de Geografía y Ordenación del Territorio and Instituto Universitario de Investigación en Ciencias Ambientales de Aragón (IUCA), Universidad de Zaragoza (Spain); ${ }^{2}$ Laboratorio de Geoarqueología, Facultad de Ciencias Naturales, Universidad Nacional de Tucumán and CONICET (Argentina); ${ }^{3}$ Dpto. de Ciencias de la Antigüedad and Instituto Universitario de Investigación en Ciencias Ambientales de Aragón (IUCA), Universidad de Zaragoza (Spain); ${ }^{4}$ Grupo de Investigación Consolidado PREHISTORIA (IT622-13), Universidad del País Vasco (Spain); ${ }^{5}$ Dpto. de Ciencias Agrarias y del Medio Natural. Escuela Politécnica Superior de Huesca, Universidad de Zaragoza (Spain) *CorrespondingAuthor: sampietro@tucbbs.com.ar

\footnotetext{
Abstract

In landscapes that are extremely sensitiveto small environmental changes, like some Mediterranean areas, archaeological contexts could present some problems to their interpretation and evolutionary reconstruction. This is the case of Los Pedregales archaeological site, located in the Hoya de Huesca (NE of Spain), whereseveral stone mounds of unknown age and function were found in an extensive badland. The geomorphological, edaphological, and archaeological study, together with radiocarbon and OSL datings and contextualization into the geomorphological regional framework, made it
} 
possible to interpret these structures and to establish an evolutionary model. It was determined that they were silos excavated in Pleistocene sands and silts (Unit 1) during the Visigothic and Early Muslim epochs $\left(6^{\text {th }}-7^{\text {th }}\right.$ centuries),and that they were later filled with limestone blocks. Successive aggradational and degradational stages (Units 2, 3 and 4) during MCA (Medieval Climatic Anomaly) and LIA (Little Ice Age) periods covered and incised the area, leaving the shape of positive structures included in the badland.

Key words: Holocene; geoarchaeology, Medieval Period; Islamic Period; badland; piping.

\section{INTRODUCTION}

Archaeological sites in drylands are always subject to conservation problems that make the interpretation of their records and paleoenvironmental reconstructions difficult. This is much more evident when a harsh environment is compounded with steep slopes, erodible lithologies, and a long and complex history of human occupation. The Tertiary depressions of the Iberian Peninsula are a clear example of this combination of unfavorable factors, especially in the Ebro Basin (NE Spain). The highly vulnerable landscapes, abrupt climate changes, and the soil misuse of this environment have frequently caused hydrological responses in aggradational/degradationalphaseson the slopes, valleys, and alluvial fans (Peña-Monné et al., 2004; Constante and PeñaMonné, 2009; Constante et al., 2010, 2011; Pérez-Lambán et al., 2014). These anthropogenic dynamics was also observed in historical times in other areas of the eastern Mediterranean (Bintliff, 2005; Butzer, 2005; Fuchs, 2007; Zielhofer et al., 2008; Bellin et al., 2013; Dusar et al., 2011; Ackermann et al., 2014), in 
the SW of the United States (Huckleberry et al., 2013; Onken et al., 2014), and in the drylands of South America (Peña-Monné and Sampietro-Vattuone, 2016).

In some cases, the occurrence of multiple processes on the landscape produces particular morphologies that can be misinterpreted. This is because the degradational processes generate anthropogenic features that prompt simplistic ideas of the archaeological site genesis. Only a detailed analysis of multiple components ina geomorphological perspective, will lead to valid interpretations and a geoarchaeological reconstruction (Peña-Monné and Sampietro-Vattuone, 2014). These interpretations will also be much more complex than those initially produced. An understanding of the regional evolutionary geoarchaeological model facilitates a genetic interpretation, which makes it possible to articulate all, or almost all, of the components of the system in a coherent way (Peña-Monné and Sampietro-Vattuone, 2014).

The purpose of this paper is to present an application of this reconstructive process in order to solve a complex archaeological problem discovered in the Ebro Basin. This area is characterized by the presence of a large number of individual accumulations of stones ('pedregales'). These accumulations seem to be aligned and would initially appear to be stone tumuli partially collapsed by erosion. This paper presents a detailed geoarchaeological study of the structures and their environment. The identification of the type of structures, their functionality, and chronological location has shown the value of the proposed technique.

From the geoarchaeological point of view, this paper constitutes the first approach to the study of detailed complex evolutionary processes of the Mediterranean area. Archaeologically, is the first notice of this nature to the 
study of the transition between Visigothic and Early Muslim times, almost unknown in the NE of Spain.

\section{GEOLOGICAL AND GEOGRAPHICAL BACKGROUND}

Los Pedregales archaeological site is located to the south of the villages of Lupiñén and Ortilla (province of Huesca), in the northern central section of the Ebro Basin, to the west of the city of Huesca (Fig.1). Thestudy area is part of the Pyrenean piedmont, traversed by the network of the Sotón River (a tributary of the Gállego River and part of the Ebro Basin). In this area, the Sotón River runs across a depressed plain known as the Hoya de Huesca (490 masl). This basin is cut by a fluvial network over soft Tertiary sediments. To the north, the basin is bordered by the Pyrenean front and the Tertiary conglomerates located to the margin of the Ebro River. To the south, the border is a Miocene limestone mesa (Saso Plano $584 \mathrm{~m}$, La Atalaya $440 \mathrm{~m}$ ). This type of relief (known as 'muela') is typical of the center of the Ebro basin (Gutiérrez Elorza and Peña-Monné, 1998).

Geologically, this section of the Pyrenean piedmont is composed of Late Oligocene continental deposits (Ageniense). These deposits belong to the distal area of the alluvial fans and are formed by clays and marls with sandstone channels, as well as some limestone levels. The materials belong to the Sariñena Formation (Quirantes, 1978; Riba et al., 1983) and are part of the Torrente del Cinca-Alcolea de Cinca Unit (del Olmo et al., 1995).

The climate of Lupiñén village, located two km from Los Pedregales, is Mediterranean continental (type Csb) according to the Köppen classification. The annual average temperature is $12.0^{\circ} \mathrm{C}\left(4.3^{\circ} \mathrm{C}\right.$ in January and $20.4^{\circ} \mathrm{C}$ in 
July). Average annual precipitations are $499 \mathrm{~mm}$, spread throughout the year with small equinoctial maximums and high intensity events during the summer.

The scarce vegetation is steppe type, with common species such as Tymus vulgaris, Brachypodiumretusum, Lygeumspartum and Stipa sp. pl. Plantagomaritimasubsp.serpentinais found inside the gullies- having adapted to ruderal environments and temporally flooded areas with salty clays (Longares, 2004).

Los Pedregales archaeological site is located to the south of the Sotón

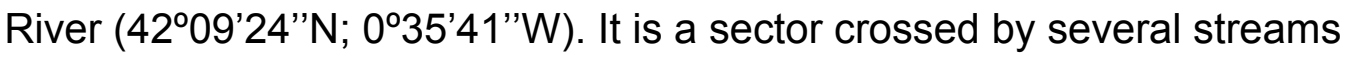
leading down from the southern limestone platforms and forming deep incisions in the marly clay substrate. Badlands are developed in some places. This erosion is intensified by the occasional presence of Quaternary loamy sand fluvial accumulations found in the valley of the Sotón River. The archaeological site is located inside one of these gullies, where erosion processes are increased by sand and gravel extraction, and its present use as a debris and garbage dump. These activities, along withthe combination of circumstances, negativelyaffectsite conservation. In fact, it is possible to observe a progressive degradation of the soon-to-disappear archaeological structures.

\section{METHODOLOGY}

This research workwas developed in two simultaneous studies: a geomorphological study ofLosPedregales surroundings, from the Tertiary platforms to the Sotón River, aimed at establishing the context; and an archaeological dig aimed at determining the nature, chronology, and function of the structures. 
For the geomorphological study, we first prepared a geomorphological map using orthoimages from the Servicio de Información Territorial de Aragón (SITAR, 2012), aerial photographs from a 1956 American flight, and Google Earth images (2013). During the fieldwork, transversal and longitudinal profiles were made using two GPSs (Trimble Geoexplorer GNSS and Garmin Montana 650). These profiles include the slopes ofLaAtalaya platform and accumulation levels of the lower areas of the Sotón River. A sample of the silty sand substrate (Fig.2) was took for OSL dating (Laboratorio de Datación y Radioquímica de la Universidad Autónoma de Madrid, MADN). Simultaneously, a detailed survey of the archaeological remains was made inthe different landscape units.

During these archaeological surveys, conducted between 2010 and 2014, all visible structures were positioned with GPS and introduced into a GIS using QGIS v. 2.14. Archaeological excavations were then made by selecting six representative units. Surficial archaeological materials and charcoal samples for anthracological studies were also collected. Two charcoal samples were dated in the Groningen University Laboratory (samples Pedregales 1 and Pedregales 2, Fig. 2). Datings were calibrated using Calib v.7 over the INTCAL13 curve and expressed with one sigma.

Soil profiles were described $(F A O, 2006)$ and soil samples were collected for physical and chemical analyses, conducted according to standard methods. All the samples were air-dried and sieved to $2 \mathrm{~mm}$. The particle size distribution was determined using the pipette method (Gee and Bauder, 1986). Soil pH was determined potentiometricallyat a 1:2.5 ratio in $\mathrm{H}_{2} \mathrm{O}$ (McLean, 1982). Total carbonate content was measured volumetrically (with a calcimeter) (Nelson, 1982). Total soil organic $C$ was determined by the method of wet oxidation 
(Nelson and Sommers, 1982); organic matter was estimated using the van Bemmelen factor $(1,724)$. Soil salinity and soluble anions were evaluated by measuring the electrolytic conductivity (ECe) of the saturation paste extract at $25^{\circ} \mathrm{C}$ (Rhoades, 1982). Soil sodicity was measured as the sodium adsorption ratio (SAR), according to the US Salinity Laboratory Staff (1954).

\section{RESULTS}

From a geomorphological perspective, the area of Los Pedregrales is a piedmont located between the southern limestone mesas and the Sotón River (Fig. 2). Two units were identified: (a) Tertiary reliefs with slopes covered by Quaternary sediments, and (b) a vast plain formed by the fluvial network of the Sotón River and alluvial fansat the valley bottom. Both areas show records of various evolutionary chronologies and have related geomorphological dynamics.

\subsection{The slopes of the southern sector}

Among the scarps of the limestone platforms and the bottom of the valleys several episodic slope accumulations took place. At the head of the streams that flow to Los Pedregales area these slopes were formed while the scarp retreated forming accumulation of different ages (Fig. 3). The older slopes (S4 and S3) have been disconnected from the headers by the incision of streams. Triangular facets or talus flatiron (Gerson, 1982) shapes have been generated. These slopes are also disconnected from the present level of terraces of the Sotón River (the original base level). The S4 accumulation has an elongated shape corresponding to the lower area of the old slope and its link 
to a remnant of a pediment flatiron (Schmidt, 1994). If we enlarge the profile of the S4 slopeand place it parallel to the present slopes, theold slope would connect to a hypothetical limestone scarp 60-70 m longer than the present one. In the same way, slope S3 (with an inner position), has its talus flatirons oriented towards the Tertiary platform - as well towards the front of the S4 slope, thereby showing a paleovalley profile (Fig. 3). Following the same method, the scarp corresponding to S3 slope was projected 20-25 m from the present scarp.

The two younger slopes (S2 and S1) are better preserved, and closer to the present structural relief. The S2 slope is a well-defined talus flatiron separated by two incisions. In some places it is prolonged through the valley by isolated alluvial fans. In one of the talus flatirons of S2 slope, a ceramic potsherd of Bronze Age was found, indicating thatits formation took placeafter this period. The S1slopeis still in contact with the top section of the platforms. It is possible to see two levels (a younger one: S1b andan older one S1a), which are slightly separated(1-1.5 m apart). At present, some gullies and rills are starting to affect these slopes, but the north facing orientationfavors good vegetation cover, which slows down erosion.

\subsection{Themorphosedimentary units of the valley}

The lower area of Los Pedregales is composed of two main overlapping units. These are also present in other badland areas of the region. The lower one was termed Unit 1 (U1) and the upper one Unit 2 (U2) (Fig. 4). In the areas still unaffected by incision processes, U2 forms a gently sloping plane from the foot of the S1 slopes to the Sotón River and U1 is unexposed. Near the river, 
where it is possible to see some outcrops, U1 deposits have disappeared and $\mathrm{U} 2$ materials are overlapping the marl and clay substrate with an irregular base.

As indicated, the $\mathrm{U} 2$ surface could be laterally related tothe $\mathrm{S} 1$ slope accumulations. The badland of Los Pedregales was developed after the U2 surface was destabilized. In the inner area of the incision of Los Pedregales, two other accumulative stages forming stepped terraces were identified andtermed U3 and U4 (Fig. 4).

Unit 1 is white and ochresediment composed of well-stratified silty sand. Its visible thickness varies from 2 to $4 \mathrm{~m}$ andthe Tertiary substrate is not observable in the badland outcrops. This unit has fluvial structures corresponding to a low-energy environment. It was not possible to find paleontological, archaeological, or organic interbedded levels. Fine sand samples were taken from the upper section of U1 to make OSL datings (Fig. 5, Table 1). A date of $21355 \pm 1118 \mathrm{BP}$ was obtained (meaning that the deposit was formed during the Later Pleistocene, coincident with the Last Glacial Maximum). In a regional perspective, there is no other information about the evolution of the Pleistocene and almost all Holocene alluvialplains until the formation of the younger Holocene units.

Unit2 is composed of fine sediments mixed with angular and scattered calcareous gravels. These sediments correspond to the distal section of an alluvial fan whose longitudinal gradient is around $1.8 \%$ (Figs. 4a, b). This composition is due to the characteristics of the basin source area: a small watershed located in the east central corner of our study area. Another major basin is situated directly in front of Los Pedregales - but its course turns sharply to the SW and its cone shifts in that direction (Fig. 2). This second stream 
transports coarser sediments (gravel and blocks) and develops a thick layer covering the western side of $\mathrm{U} 1$. The $\mathrm{U} 2$ accumulation contains abundant disperse potsherds, althoughthere is no evidence of in situ human activities. The erosion of fine sediments from the U2 level through the interior of the incisions causes the development of small cones with several pottery fragments coming from the unit, and these provide information about archaeological materials (Fig. 5a, b). According to theirtypology, these correspond to the Roman and Medieval periods. A large fragment of pottery painted with waves and bands was found at the base of U2 (Fig. $5 \mathrm{~d}$ ) without evidence of transportation. This piece probably corresponds to the $11^{\text {th }}$ century (Picazo et al., 2016). A coin was found at the base of the profile in a small cone of fine sediments formed by a piping (Fig. 5e). It was minted under Felipe IV in 1641 at Solsona (Catalonia).

In addition to the chronological separation between $\mathrm{U} 2$ and $\mathrm{U} 1$, there aremajor physicochemical differences (Fig. 6): U2 is darker, has a loamy texture and higher organic matter content than U1. The electric conductivity values (ECes), sodium adsorption rate (SAR), and cation exchanger concentration $\left(\mathrm{Na}^{+}, \mathrm{Mg}^{2+}\right.$, and $\left.\mathrm{Ca}^{2+}\right)$ corroborate this difference between the compositionof the two units. It is possible to recognize two sublevels in $U 1$ (U1a and U1b) with loam-clayey and loamy textures, respectively (Fig. 6).

From an edaphic point of view, U2 is a young soil with plenty of bioturbations (filled worm galleries). The soil has a sequum $\mathrm{Ah}-\mathrm{C}$, with a subangular blocky and a laminar structure. This soil is classified as Calcaric Sodic Regosol (IUSS, 2015) and as Typic Xerorthent (Soil Survey Staff, 2014), 
according to Badía (2009). These characteristics are in agreement with its young age.

Soil erosion causes the development of abrupt escarpments without ruptures or other features. Given the geochemical differences (Fig. 6), the hydrogeomorphological behaviors of U1a and U1b differ. Previous micromophological studies of these subunits showed the presence of textural microstratification that produces changes in the porosity and water infiltration (Badía, 2009). This is reflected by micro modeling and is also responsible forthe rapid development of erosion and widening of the badland. Both units have very high SAR values ( $>45)$ and low or moderate CEe $(<8 \mathrm{dS} / \mathrm{m})$; these variables are determinant of clay dispersion and trigger erosion processes - especially piping. These relationships have been indicated by Jones $(1981,1994)$. In addition to a high dispersion of sediments, other important factors favor piping processes in the same area (Jones, 1981; Bryan and Yair, 1982; Imeson et al., 1982) as well as in some areas of the Ebro Basin (Benito et al., 1993; Gutiérrez et al., 1997; García-Ruiz et al., 1997), and the SE of Spain (Harvey, 1982; LópezBermúdez and Romero Díaz, 1989). The variables present in our study area include: climates with strong seasonal contrasts and rainfall variability; the formation of surficial contraction cracks; the existence of a hydraulic gradient; and the presence of ruptures or changes in porosity across lower levels.

The intense erosion linked to the piping processes at Los Pedregales results fromthe development of an extensive area of gullies (with headward erosion) that finally forms badlands as a result of the dispersive subsoil (Faulkner, 2013). The division between U1a and U1b shows changes in composition reflected in the evolution of micro morphological modeling (Fig. 5a, 
b) as revealed by a shoulder where several pipe outlets emerge, together with popcorn surfaces and columnar structures (following hexagonal cracks produced by volumetric clay changes). There are also some micro-rock pedestals (Fig. 5a, b, c) generated by the presence of gravel and potsherds deposited after the leaching of the upper unit (U2). The precipitation of a salt layer is evident over the U1 surfaces (Fig. 5a).

From an evolutionary perspective, after the formation of an alluvial fan (U2) an incision process started through the action of several streams and the main river. A wide gully was generated and branched expansively into a complex design along several successive stages. The same evolution was observed in other small gullies in the area, although none is as complex as Los Pedregales.

In some sectors the incision is wider and it is possible to see a new accumulative stage (U3). These deposits are represented by a short ramp in the scarp of U2, or bynarrow deposits in the interior of the main gully that was the temporal alluvial bed (Figs. $4 a, b)$. The gradient is around $2 \%$. The deposits of this new unit are 0.15 to $0.20 \mathrm{~m}$ thick. They are fine and reworked from previous deposits, which means that there is no external input. However, it is possible to see some small terraces composed of calcareous gravels (Ugr) (Figs. 4a, b) with a channeled fluvial structure inU3. These gravels were deposited at the same stage, as a consequence of flooding from the main stream (located to the west), which overflowed the channel through the gully of Los Pedregales. The channel is still visible on the land (Fig. 2). The U3 aggradation phase temporally slowed the erosion - but it restarted later to continue until the present. The new 
channel runs among the old accumulations and its general gradient is around $1.4 \%$ (Figs. $4 a, b)$.

The result is a complex micro landscape (Figs. 4 b, c) in which the scarps formed by $\mathrm{U} 2$ and $\mathrm{U} 1$ stand out. At a second level, there are many isolated U3 and Ugr deposits. In addition to these geomorphological units, it is possible to identify the set of anthropogenic mound blocks - still prominent due to the protection of the fallen blocks (Figs. 4b, c).

\subsection{The archaeological context}

The stone mounds on the western side of the gully of Los Pedregales immediately attract attention (Fig. 7). This is because there are no stones of that size in the area, and their conical shape suggests that they have been severely degraded. Moreover, it is possible to observe an abundance of potsherds and animal bone fragments. These ceramic fragments belong to Roman, Medieval, and Modern periods, and are dispersed along the whole surface. As indicated,some profiles showedthat U2 contains potsherds (Fig. 5d) and its erosion through micro rills and piping provides numerous fragments to the badland (Fig. 5b). It was even possible to locate a coin coming from the same deposit (Fig. 5e).Therefore, U2 was shown to be the source of much of the dispersed material.

A survey of superficial deposits made it possible to establish that the only in situ remains are stone accumulations, whose arrangement, after the GIS analysis, has no precise alignment (Fig. 7). We were able to locate 57 subcircular isolated structures, with different degrees of conservation, many of them with mound shapes forming a stone cone of limestones of diverse sizes (Fig. 
$8 a, b)$. These cones are sometimes topped by a large flat limestone. Some structures appear deteriorated and the blocks are dispersed, but it is possible to infer their presence by changes in the color of the inner sediments. This sediment is grayish with a high presence of micro-charcoals that are very visible over the yellowish U1 sediments (Fig. 8c).

Some archaeological excavations were made to establish the origin, function, age, and relationship of the structures with the geomorphological evolution of the badland. Five well preserved structures were selected $(1,2,3$, 6, and 9). The ceramic potsherds and bones exposed by erosion were collected in other points.

After excavation it was possible to determine that they were negative silo-like structures, excavated on the fine U1 sediments. These globular pits had planar bottoms;in some cases their walls were relatively vertical or concave in the sections with thelargest diameter (around $1.5 \mathrm{~m}$ maximum). The general profile enabled us to reconstruct a closed shape with a narrow mouth. It was not possible to observe the entire shape because of collapses. The poor general conservation of the area did not make it possible toestimate the depth of these pits (although they were probably more than $1.4 \mathrm{~m}$ deep according to the position of the badland fill).

Inside the excavated structures, gray ceramics from the High Medieval Period accompanied by bones, mainly of sheep and goats, were found (Fig. 8d) and by bonesof other species in some isolated cases (Sierra et al., 2016). Charcoals of different sizes were also recovered, as well as a large volume of micro charcoal and wood ash (for a detailed analysis of archaeological materials see Picazo et al., 2016). Two charcoal pieces from the inner fill of two 
structures were dated to $1520 \pm 30 \mathrm{BP}(437-596 \mathrm{cal} A \mathrm{D} 1 \sigma)$ and $1300 \pm 30 \mathrm{BP}$

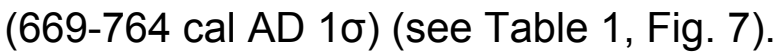

According to the information recovered from the archaeological excavations, Los Pedregales archaeological site was an extensive silo field, where at least 50 structureswere identified. The potsherd and radiocarbon datings obtained from the infill of the units demonstrated that they were used at least fromthe second half of 6 th century until the early 8 th century - and were then abandoned. Accordingly, the silo field is from the Visigothic and Early Muslim epochs. Moreover, above eroded structure number 6, a Muslim coin dated to the Independent Emirate (711-756 AD) was found, thereby supporting the radiocarbon datings (Picazo et al., 2016).

The limestones accumulated in a tumular shape are the intentional infilling of the silos abandoned after disuse, with stones carried from the closest stream around $400 \mathrm{~m}$ behind (given that only fine materials were found in the gully). The blocks were deposited inside the pits in a disorderlymanner. The current disposition resulted from the erosion of the earth walls that contained the blocks before the erosion of the fine U1 sediments. Blocks from the central part remained in situ while those located at the margins were moved to the lateral incisions. This process started when a drainage network excavated in the surrounding areas became much deeper than the level of the silo base. The result is a set of apparently positive tumular structures dispersed in the badland because limestones are harder than U1 sediments. Moreover, the stones protected the remnants contained in the structures and enabled the conservation of ashes, charcoals, and Visigothic and Muslim potsherds. The 
described process explains why the first impression is that of a set of stone mounds with an unknown function inside the badland.

\section{DISCUSSION}

The geomorphology of Los Pedregales area shows an evolution that resembles that of other areas in the Ebro Basin. The Tertiary continental horizontal structures generated structural platforms or 'muelas', at the foots of which several Pleistocene and Holocene slopes are preserved. These slopes are the consequence of cyclical aggradational/degradational processes resulting from stages of stability and incision (Sancho et al., 1988; Gutiérrez et al., 1998). At a regional level, the youngest phases, S2 and S1, can be associated with the Iron Age Cold Epoch (2700-2500 BP) and the Little Ice Age (1300-1850 BP), respectively (Peña-Monné et al., 1996; Gutiérrez and PeñaMonné, 1998). In both cases, these stages are coincident with cold and wet environmental conditions that favored slope stabilization (Gutiérrez and PeñaMonné, 1998; Pérez-Lambán et al., 2014; Peña-Monné and Sancho, 2014). The presence of a Bronze Age ceramic potsherd in one of the talus flatirons of S2 phase around Los Pedregales site made it possible to relate the age of this accumulation to that of other contemporary slopes with similar topographic locations (Pérez Lambán et al., 2014). Moreover, the S1 phase, represented by two subslopes (S1a and S1b), may belong to two periods of the LIA, as indicated ina similar site to the south of Zaragoza (Pérez-Lambán et al., 2014). The second subslope is contemporaneous or subsequent to the $18^{\text {th }}$ century.

Unit 2 constitutes an extensive alluvial fan related to the S1b slope thatextends to the Sotón River. This stage was dated at Los Pedregales 
archaeological site for the period between the 11th century (by the presence of an uneroded potsherd found at its base, Fig. $5 \mathrm{~d}$ ) and the $17^{\text {th }}$ century (coin found from 1641 belonging to the same level). Unit 2,as well as its young and little developed soil, belongs to the LIA.

Establishingthe age of $\mathrm{U} 2$ is important for defining the aspects related to the excavation of the silo pits, and for defining part of the chronology of the evolutionary model. As there is no complete profile of these structures in the inner area of the U1-U2 units at any place where they overlie, it is still unknown over which surface they were excavated. We know the age of U1 (Late Pleistocene according to its OSL dating), and we know that the silo pits were excavated on the clayey silt sediment. From the dates obtained for the silo sediments between the second half of the $6^{\text {th }}$ century and the start of the $8^{\text {th }}$ century - it is easy to deduce that U2 did not exist at that time. Therefore, the silos had to be excavated directly on $U 1$, which sediments were not covered by younger deposits as it was pointed before.

Moreover, the radiocarbon datings and ceramic contents of the silos enable one to determine that all or at least some of them, were excavated and built before the second half of the $6^{\text {th }}$ century (Fig. 9.0, 9.1) and were used between the $6^{\text {th }}$ and $8^{\text {th }}$ centuries (Fig. 9.2). They were later abandoned andfilled with limestone after the $8^{\text {th }}$ century (Fig. 9.3). Unfortunately, as the settlements of this age are regionally little known (Picazo et al., 2016), it is not possible to contextualize them in a wider perspective. Nevertheless, they constitute a relevant sample of this kind of settlements, as well as of the processes involved in their evolution. 
During the LIA, the formation of the slopes of the nearby reliefs and the drainage network favored the formation of an extensive cover represented by the alluvial fan (U2), whose base level is the Sotón River. This deposit covered U1 and the Early Medieval structures already abandoned and filled. The set composed of these two elements has remained completely invisible on the surface since the $17^{\text {th }}$ century (Fig. 9.4). Considering a regional framework there are several data about the geomorphological dynamics generated by the high climatic variability of the LIA. In the alluvial bottoms of the center of the Ebro Basin, phases of incision and accumulation were produced, forming two terraces during this period (Peña-Monné et al, 2004). In the same way, in the slopes it is possible to see accumulations formed during that ages affected by incisions (Pérez-Lambán et al., 2014) as a result of the alternative phases of runoff activity. On these papers, two dynamic phases of the LIA were established, one before the 17 th century and the other after such times. These phases, as it was already pointed, are present in our study area (S1a and S1b).

Under these highly dynamic environmental conditions produced by the LIA thearchaeological structures were exhumed. The process was started by the progressive erosion of $U 2$, reaching the highly erodible sediments of $U 1$. This erosive process continues today with stable intermediate phases during which the bottom of the gully is temporally stabilized.

The badland formation was a very quick piping process with superficial erosion and permanent lateral erosion of the scarps. These processes were favored by the following factors: high dispersion of the clays because of the sodicity of $U 1$; high intensity rainfalls; the formation of contraction cracks that allow rapid inner water infiltration; and the rapid deepening of incisions that 
create a high vertical gradient. In addition, the archaeological structures favored water infiltration through the discontinuities resulting from the old excavations that strengthened the piping processes. Inner blocks were gradually left on the surface and took on the shape of a mound (Fig. 9.5).

At some point in time, the bottom of the area was stabilized by a new aggradation phase (U3). This stage formed a fill that stopped the erosion process for a short period. This accumulation appears linked to several archaeological structures (Fig. 9.6). During this phase a neighboring stream located to the west of Los Pedregales changed its channel, flooding the area and depositing a layer of gravel forming unit Ugr (Fig. 9.7). The bottom erosion process, together with the lateral erosion of the U1-U2 scarps, then restarted,and a new infill corresponding to the U4 unit was developed. Small channels are sometimes created over the unit during heavy rainfall (Fig. 9.8).

\section{CONCLUSIONS}

Los Pedregales archaeological site and its surrounding area demonstrate the importance of evolutionary geoarchaeological models for the correct understanding of highly complex archaeological sites. These models are also highly suitable for incorporating all the contextual elements needed to make well documented interpretations.

At first sight it is possible to see at Los Pedregales a set of positive mounds with unknown functionality and chronology. These mounds are located in a highly erodible environment, which contributes to their reconstructive complexity. 
Once the sediment characteristics, together with the evolutionary stages and their chronology, were understoodit was possible to work towards making a correct interpretation of the temporal sequence. This made it possible to integrate local information into a regional framework.

Contrary to expectations, the archaeological structures of Los Pedregales were found to be pits built in highly unstable sediment (U1). These pits served as excavated silos and were used between the Visigothic Epoch (second half of the 6th century) and the Early Muslim Epoch (8th century).

After abandonment, the pits were intentionally filled with limestone. An aggradation phase occurred after the 8th century and persisted until the17th century (first half of the LIA), generating the sedimentation of the alluvial fan (U2). The chemical characteristics of this unit are very different from and more stable thanthose of $U 1$. These sediments covered the archaeological structures and soil was formed. During the second stage of the LIA, and following high climatic variability, several incision processes began. These processes gradually reached the U1 sediments, accelerating erosion processes and forming Los Pedregales badland. This process uncovered the remains of the Early Medieval structures, which gradually acquired a tumular shape, evolving in successive aggradation(U3, U4) and incisive phases.

It is still not possible to contextualize our archaeological findings in a wider framework, given the fact that there are no references for archaeological sites corresponding to those times. However, the archaeological information provided in this paper is highly significant,especially considering the processes involved and the reconstructive model made to explain the regional behavior of this kind of archaeological sites. 


\section{Acknowledgments}

This work is a contribution of the Quaternary Paleoenvironments Research Group (PALEOQ) and PrimerosPobladores del Valle del Ebro Research Group (PPVE) (Aragón Government and European Regional Development Fund) and IUCA (Enviromental Sciences Institute of the University of Zaragoza). It has been supported the HAR2012-36967 project "Dinámica de la ocupaciónprehistórica en el vallemedio del Ebro durante el Holoceno Superior" of the Spanish Government and the European Development Fund, and a grant for Invited Professors from Campus Iberus 2014. We want to thank to the Ayuntamiento de Lupiñén-Ortilla for the aid to make the excavations. Also to the archaeologists Jonathan Terán and Alejandro Martín, and to the geographer MaríaRoyo from the University of Zaragoza.

\section{References}

Ackermann, O., Greenbaum, N., Ayalon, A., Bar-Matthews, M., Boaretto, E., Hendrik J. Bruins, H.J., Dan Cabanes, D., Horwitz, L.K., Neumann, F.H., Porat, N., Weiss, E., Maeir, A.M., 2014. Controls on sedimentation rates, Tell esSafi/Gath, Eastern Mediterranean. Anthropocene 8, 70-82.

Badía, D. (Coord.), 2009. Itinerarios edáficos por el Alto Aragón. Ed. Instituto de Estudios Altoaragoneses, Huesca. http://www.secs.com.es/wpcontent/uploads/2014/01/27-Reuni\%C3\%B3n-SECS.-Huesca-2009.pdf (accessed 16.08.18). 
Bellin, N., Vanacker, V., De Baets, S., 2013. Anthropogenic and climatic impact on Holocene sediment dynamics in SE Spain: A review. Quaternary International 308-309, 112-129. http://dx.doi.org/10.1016/j.quaint.2013.03.015. Benito, G., Gutiérrez, M., Sancho, C., 1993.The influence of physico-chemical properties on erosion processes in badland areas, Ebro basin, NE Spain. Z. Geomorphol. N.F. 37, 199-214.

Bintliff, J., 2005. Human impact, land-use history, and the surface archaeological record: a case study from Greece. Geoarchaeology 20(2), 135147. http://dx.doi.org/10.1002/gea.20040.

Bryan, R.B., Yair, A., 1982. Perspectives on studies of badland geomorphology.In: Bryan, R., Yair, A. (Eds.), Badland Geomorphology and Piping. GeoBooks, Norwich, pp. 1-12.

Butzer, K.W., 2005. Environmental history in the Mediterranean world: crossdisciplinary investigation of cause-and-effect for degradation and soil erosion. Journal of Archaeological Science 32(12), 1773-1800. http://dx.doi.org/10.1016/j.jas.2005.06.001.

Constante, A., Peña-Monné, J.L., 2009. Human-induced erosion and sedimentation during the Holocene in the Central Ebro Depression, NE Spain. Murcia, Spain. In: Romero, A., Belmonte, F., Alonso, F., López-Bermúdez F. (Eds.), Advances in Studies on Desertification. Universidad de Murcia, pp. 207210.

Constante, A., Peña-Monné, J.L., Muñoz, A., 2010. Alluvial geoarchaeology of an ephemeral stream: implications for Holocene landscape change in the central part of the Ebro Depression, northeast Spain. Geoarchaeology 25 (4), 475-496. http://dx.doi.org/10.1002/gea.20314. 
Constante, A., Peña-Monné, J.L., Muñoz, A., Picazo, J.V., 2011. Climate and anthropogenic factors affecting alluvial fan development during the late Holocene in the central Ebro Valley, northeast Spain. The Holocene 21, 275286. http://dx.doi.org/10.1177/0959683610378873.

Del Olmo, A., Hernández, A., Salazar, A., 1995. Mapa Geológico de España escala 1:50.000 Almudévar. Inst. Tecnológico y Geominero de España, Madrid. Dusar, B., Verstraeten, G., Notebaert, B., Bakker, J., 2011. Holocene environmental change and its impact on sediment dynamics in the eastern Mediterranean.Earth-Science Reviews 108 (3-4), 137-157. http://dx.doi.org/10.1016/j.earscirev.2011.06.006.

Faulkner, H., 2013. Badlands in marl lithologies: A field guide to soil dispersion, subsurface erosion and piping-origin gullies. Catena 106, 4253.http://dx.doi.org/10.1016/j.catena.2012.04.005.

FAO, 2006.Guidelines for soil description. 4th edition. Roma.

Fuchs, M., 2007.An assessment of human versus climatic impacts on Holocene soil erosion in NE Peloponnese, Greece.Quaternary Research 67, 349-356. http://dx.doi.org/10.1016/j.yqres.2006.11.008.

García-Ruiz, J.M., Lasanta, T., Alberto, F., 1997. Soil erosion by piping in irrigated fields. Geomorphology 20, 269-278.http://dx.doi.org/10.1016/S0169$555 \times(97) 00028-7$.

Gee, G.W., Bauder, J.W., 1986. Particle-size analysis.In: Klute, A. (Ed.), Methods of soil analysis. Part 1: Physical and mineralogical methods, 2nd edition. American Society of Agronomy. Madison, Wisconsin, pp. 383-412. Gerson, R., 1982. Talus relict s in deserts: A key to major climatic fluctuations. Israel Journal of Earth-Sciences 31, 123-132. 
Gutiérrez, M., Sancho, C., Benito, G., Sirvent, J., Desir, G., 1997.Quantitative study of piping processes in badland areas of the Ebro Basin, NE Spain.Geomorphology 20, 237-253. http://dx.doi.org/10.1016/S0169$555 \times(97) 00026-3$.

Gutiérrez-Elorza, M., Peña-Monné, J.L., 1998.Geomorphology and Late Holocene Climatic Change in Northeastern Spain.Geomorphology 23, 205-217. http://dx.doi.org/10.1016/S0169-555X(98)00004-X.

Gutiérrez, M., Sancho, C., Arauzo, T., 1998. Scarp retreat rates in semiarid environments from talus flatirons (Ebro Basin, NE Spain). Geomorphology 25, 111-121. http://dx.doi.org/10.1016/S0169-555X(98)00034-8.

Harvey, A.M., 1982. The role of piping in the development of badlands and gully systems in south-east Spain. In: Bryan, R., Yair, A. (Eds.), Badland Geomorphology and Piping. Geobooks, Norwich, pp. 317-335. Huckleberry, G., Onken, J., Graves, W.M., Wegener, R., 2013. Climatic, geomorphic, and archaeological implications of a late Quaternary alluvial chronology for the lower Salt River, Arizona, USA.Geomorphology 185, 39-53. http://dx.doi.org/10.1016/j.geomorph.2012.12.003. Imeson, A.C., Kwaad, F.J., Verstraten, J.M., 1982. The relationship of the soil physical and chemical properties to the development of badlands in Morocco.In: Bryan, R., Yair, A. (Eds.), Badland Geomorphology and Piping. GeoBooks, Norwich, pp. 47-70.

IUSS Working Group WRB, 2015. World Reference Base for Soil Resources 2014, updated 2015. World Soil Resources Reports n 106. FAO. Rome. Jones, J.A.A., 1981. The Nature of Soil Piping: a review of research. GeoBooks, Norwich. 
Jones, J.A.A., 1994. Soil piping and its hydrogeomorphic function.Cuaternario y Geomorfología 8 (3-4), 77-102.

Longares, L.A. 2004. Planas y estepas del sector meridional del Valle del Ebro.In: Peña, J.L., Longares, L.A., Sánchez, M. (Eds.), Geografía Física de Aragón. Aspectos generales y temáticos. Unviersidad de Zaragoza e Institución Fernando el Católico. Zaragoza, pp. 275-287.

López-Bermúdez, F., Romero-Díaz, M.A., 1989. Piping erosion and badland development in southeast Spain. Catena Supplement 14, 59-73.

McLean, E.O., 1982. Soil pH and lime requirement.In: Page, A.L., Miller, R.H., Keeney, D.R. (Eds.), Methods of soil analysis. Part 2: Chemical and microbiological properties, 2nd edition. American Society of Agronomy. Madison, Wisconsin, pp. 199-224.

Nelson, R.E., 1982. Carbonate and gypsum.In: Page, A.L., Miller, R.H., Keeney, D.R. (Eds.), Methods of soil analysis. Part 2: Chemical and microbiological properties, 2nd edition. American Society of Agronomy. Madison, Wisconsin, pp. 181-198.

Nelson, R.E., Sommers, L.E., 1982. Total carbon and organic matter, Page, A.L., Miller, R.H., Keeney, D.R. (Eds.), Methods of soil analysis. Part 2:

Chemical and microbiological properties, 2nd edition. American Society of Agronomy. Madison, Wisconsin, pp. 539-557.

Onken, J., Cook, J.P., Youberg, A., Philip A. Pearthree, P.A., 2014.

Geoarchaeological dating of Holocene stream terraces along the San Pedro River, southeastern Arizona, USA.Quaternary International 342, 20-32. http://dx.doi.org/10.1016/j.quaint.2013.10.033. 
Peña-Monné, J.L., González, J.R., Rodríguez, J.I., 1996. Paleoambientes y evolución geomorfológica en yacimientos arqueológicos del sector oriental de la depresión del Ebro durante el Holoceno superior.In: Pérez-Alberti, A., Martini, P., Chesworth, W., Martínez-Cortizas, A. (Eds.), Dinámica y evolución de medios cuaternarios, Editorial Xunta de Galicia, pp. 63-80.

Peña-Monné, J.L., Julián, A., Chueca, J., Echeverría, M.T., Ángeles, G.R., 2004. Etapas de evolución holocena en el valle del río Huerva: Geomorfología y Geoarqueología.In: Peña-Monné, J.L., Longares, L.A., Sánchez-Fabre, M. (Eds.), Geografía Física de Aragón. Aspectos generales y temáticos. Universidad de Zaragoza e Institución Fernando el Católico, Zaragoza, pp. 289-302.

Peña-Monné, J.L., SampietroVattuone, M.M., 2014. Geoarchaeological and paleoenvironmental reconstruction through evolutionary models: Dryland applications. European Geologist Magazine 38, 40-44.

PeñaMonné, J.L., SampietroVattuone, M. M., 2016. La secuencia paleoambiental holocena de la vertiente oriental de Loma Pelada (Valle de Tafí, Noroeste Argentino): cambios climáticos y acción humana.In SampietroVattuone, M.M., Peña Monné, J.L. (Eds.), Geoarqueología de los Valles Calchaquíes. Ocupaciones humanas y reconstrucciones paleoambientales del Holoceno. Laboratorio Geoarqueología, Universidad Nacional de Tucumán. Argentina, pp. 23-63.

Peña-Monné, J.L., Sancho, C., Muñoz, A., Constante, A., 2014. Clima y hombre en la evolución de las vales del sector central de la Depresión del Ebro durante el Holoceno superior.In: Arnáez, J., González, P., Lasanta, T., Valero, B.L. (Eds.), Geoecología, cambio ambiental y paisaje: homenaje al Profesor José 
María García Ruiz, 91-102. Instituto Pirenaico de Ecología (CSIC)-Universidad de La Rioja.

Pérez-Lambán, F., Peña-Monné, J.L., Fanlo, J., Picazo, J.V., Badia, D., Rubio, V., García-Jiménez, R., Sampietro Vattuone, M.M., 2014. Paleoenvironmental and geoarchaeological reconstruction from late Holocene slope records (Lower Huerva Valley, Ebro Basin, NE Spain).QuaternaryResearch 81, 1-14. http://dx.doi.org/10.1016/j.yqres.2013.10.011.

Picazo, J.V., Pérez-Lambán, F., Peña-Monné, J.L., Sampietro-Vattuone, M.M., Longares, L.A., Justes, J., Ortega, J.M., 2016. Los Pedregales (Lupiñén-Ortilla, Huesca): Contribución al conocimiento del poblamiento altomedieval en la Hoya de Huesca. Archivo Español de Arqueología 89, 225-248.

Quirantes, J., 1978. Estudio sedimentológico y estratigráfico del Terciario continental de los Monegros. Instituto Fernando el Católico, Diputación Prov. de Zaragoza (España).

Rhoades, J.D., 1982. Cation exchange capacity.In: Page, A.L., Miller, R.H., Keeney, D.R. (Eds.),Methods of soil analysis. Part 2. Chemical and Microbiological Properties.American Society of Agronomy, Inc. Soil Science Society of America. Inc. Madison, Wisconsin, pp. 149-157.

Riba, O., Reguant, S., Villena, J., 1983. Ensayo de síntesis estratigráfica y evolutiva de la cuenca del Ebro.In: Instituto Geológico Minero de España (Ed.), Libro Jubilar J.M. Ríos. Geología de España 2, pp.131-159.

Sancho, C., Gutiérrez, M., Peña-Monné, J.L., Burillo, F., 1988. A quantitative approach to scarp retreat starting from triangular slope facets (Central Ebro Basin, Spain).In: Harvey, A.M., Sala, M. (Eds.), Geomorphic processes In Environments with Strong Seasonal Contrasts. II: Geomorphic Systems. Catena Suppl. 13, 139-146. 
Schmidt, K.H., 1994. Hillslopes as evidence of climatic change.In: Abrahams, A.D., Parsons, A.J. (Eds.), Geomorphology of deserts environments, Chapman \& Hall, London, pp. 675-694.

Sierra, A., Pérez-Lambán, F., Picazo, J.V., Peña-Monné, J.L., SampietroVattuone, M.M., 2016. Estudio de los restos faunísticos de los silos altomedievales de Los Pedregales (Lupiñén-Ortilla, Huesca).In: Rodanés, J.M., Lorenzo, J.I. (Eds.), I Congreso de Arqueología y Patrimonio Aragonés, Zaragoza, pp. 459-468.

Soil Survey Staff, 2014.Keys to Soil Taxonomy. Twelfth Edition. USDA, Natural Resources Conservation Service.

Zielhofer, C., Faust, D., Linstädter, J., 2008. Late Pleistocene and Holocene alluvial archives in the southwestern Mediterranean: Changes in fluvial dynamics and past human response. Quaternary International 181, 39-54. http://dx.doi.org/10.1016/j.quaint.2007.09.016. 


\section{Figure Captions}

Fig. 1. Location map.

Fig. 2. Geomorphological map of Los Pedregales.

Fig. 3. Differentiation in the slope stages of (S4, S3, S2, S1) in the eastern sector of Los Pedregales.

Fig. 4. a) Longitudinal profiles of the four units differentiated in the Los

Pedregales badland; b) general view of the badland showing the different levels described in the text, the numbers in the circles correspond to the archaeological structure references; c) transversal profile of the badland showing present levels and the presence of each unit remnant.

Fig. 5. Micromorphological and chronological aspects of U1 and U2: a) overview of the escarpment and its microforms. The red dot indicates the location of OSL dating; b) schematic drawing of the arrangement of the microforms and archaeological sites; c) micropedestal; d) fragment of XI century ceramic found at base of U2; e) coin minted in 1641, originally from the leached part of U2 and found at the foot of the escarpment.

Fig. 6. Vertical profile of U1-U2 using analytical data.

Fig. 7. Vertical view (Google Earth 2013) of the mounds of stones found in the 
Los Pedregales badland. The numbers correspond to excavated structures.Points 1 and 2 are provenance place of the AMS samples; the asteriskmarks the OSL sample provenance.

Fig. 8. Archaeological structures at different stages of degradation; a) structure retaining blocks in original position; b) elongated remains of a structure between two incisions; c) heavily eroded base of the structure; d) remains of a bovid in structure number 9.

Fig. 9. Evolutionary stages in Los Pedregales badland (explanation in text).

\section{Table Captions}

Table 1. OSL and radiocarbon datings. 


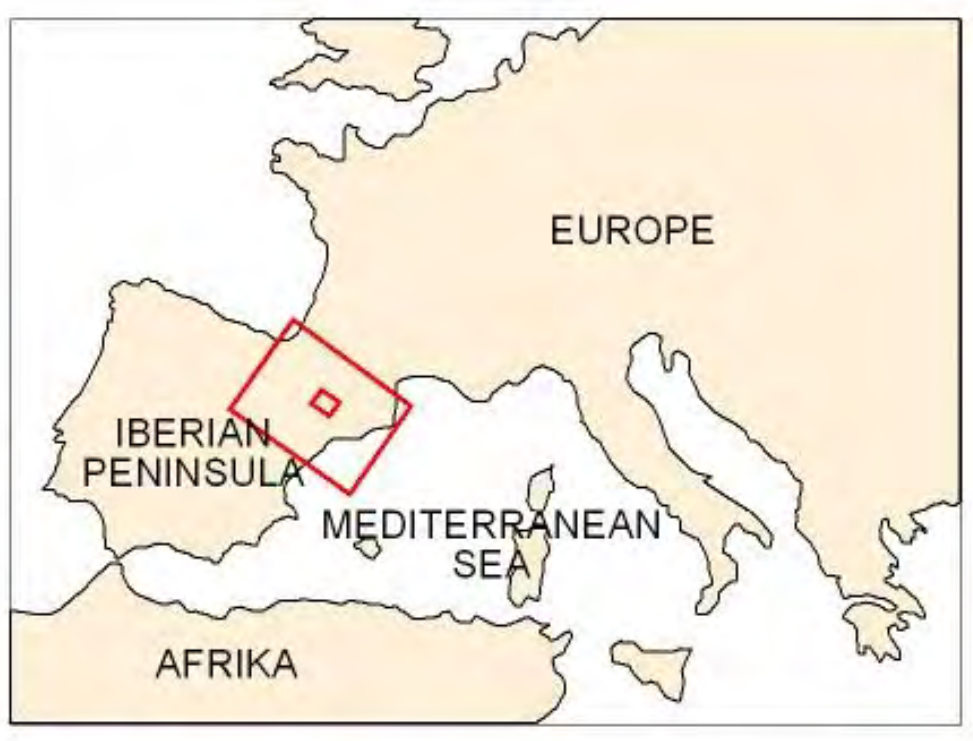

ㅁ Los Pedregales $42^{\circ} 09^{\prime} 22.18^{\prime \prime} \mathrm{N}$ $0^{\circ} 35^{\prime} 42.29 " \mathrm{~W}$

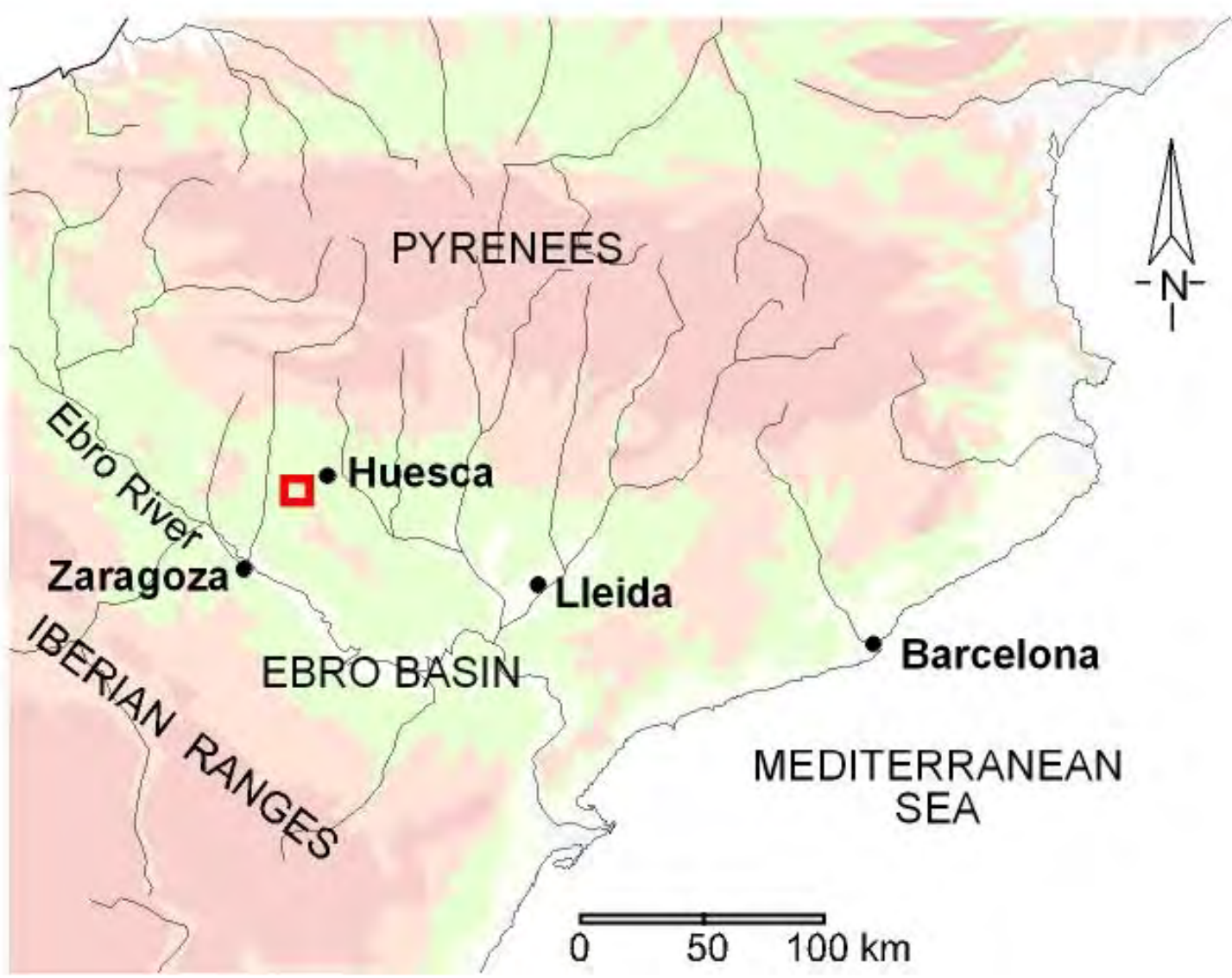




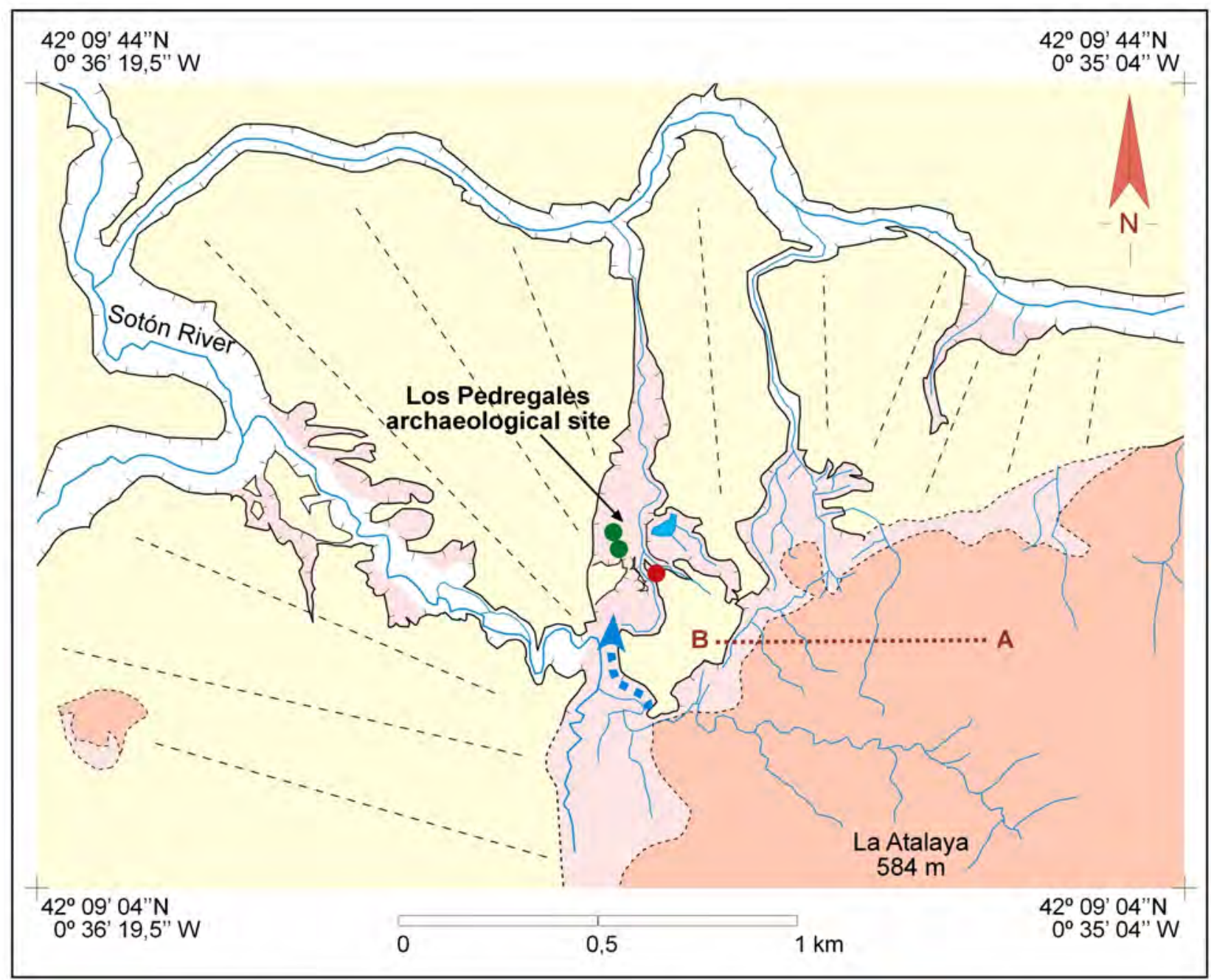

Tertiary reliefs and

Quaternary slopes

` Holocene alluvial fan U2

badlands

- ${ }^{14} \mathrm{C}$ samples fluvial network

scarpments

incision and floodplain

- OSL sample paleochannel

artificial pond

profile Fig. 3 

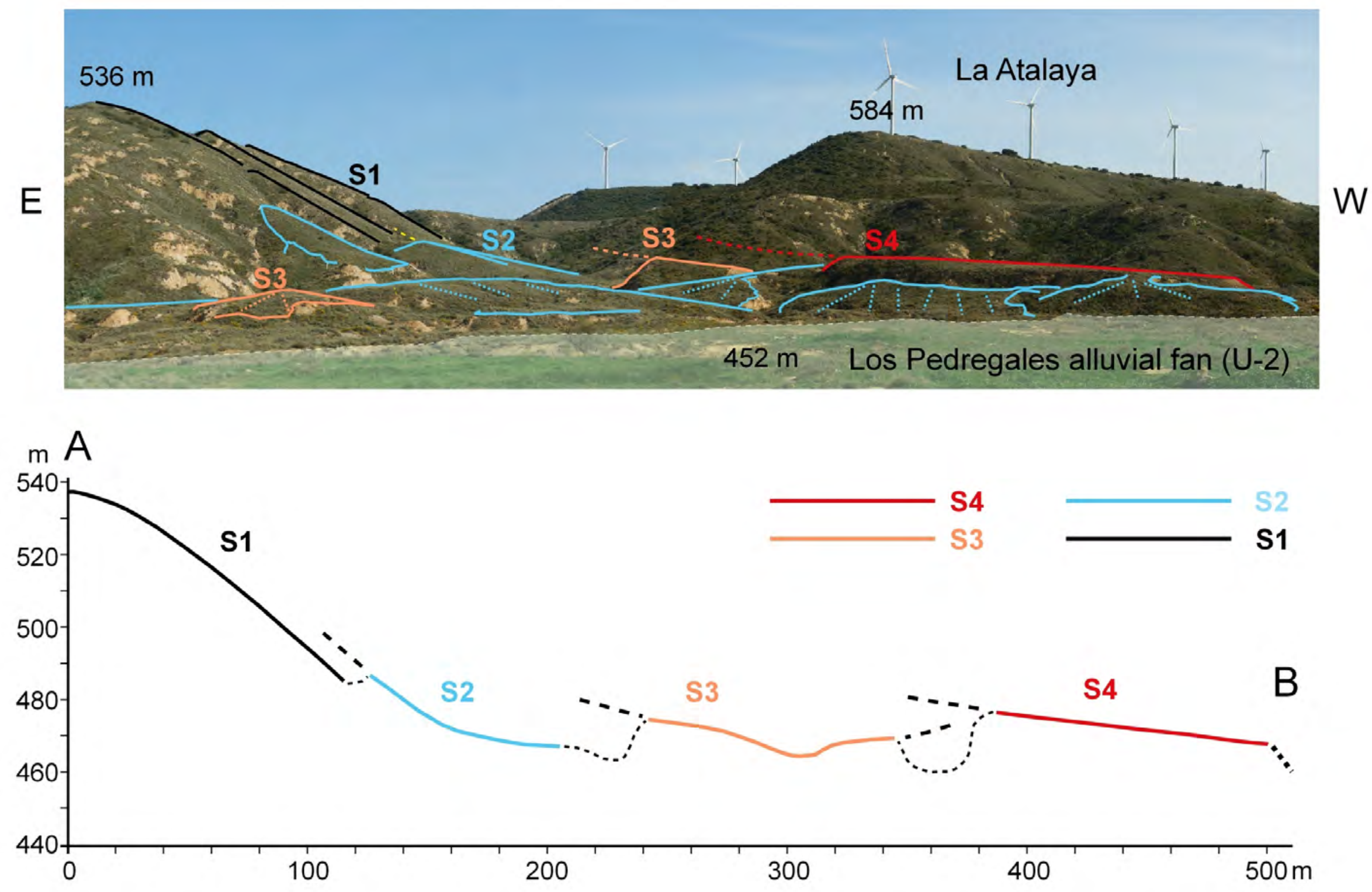
a

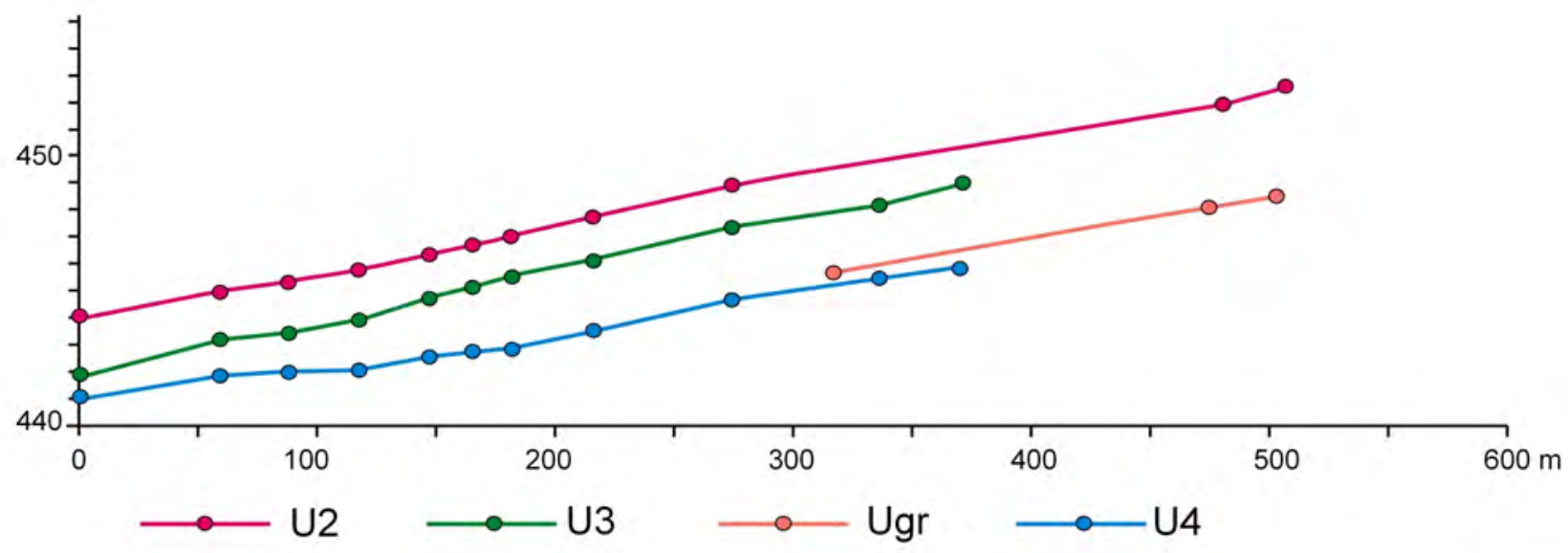

b
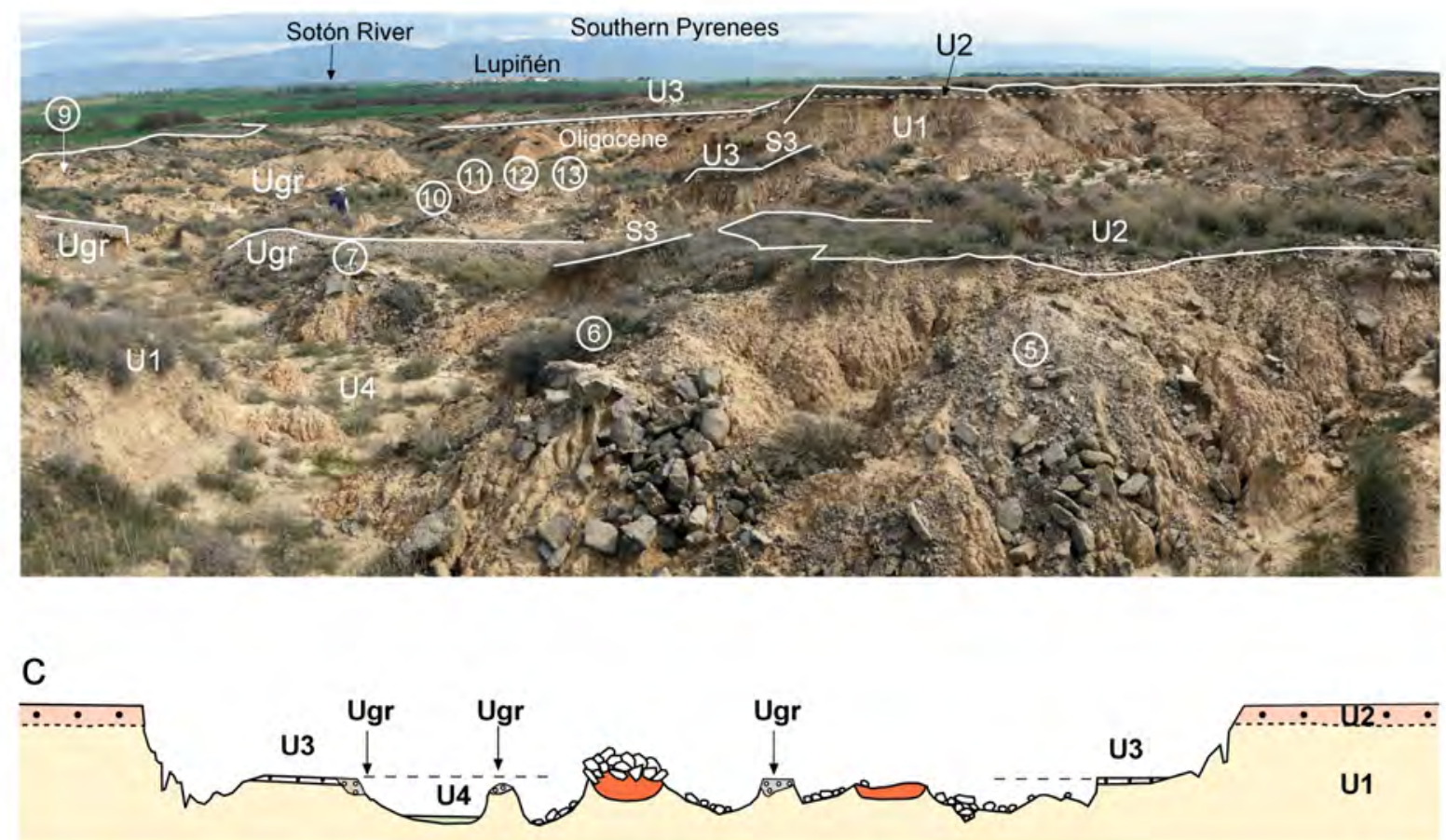

$\square$ U1 fluvial floodplain $\cdots$ U2 alluvial fan $\cdots$ U3 badland infill $\square$ U4 badland infill

$\because:$ Ugr gravels event $\square$ silo's basal infill stone mounds 

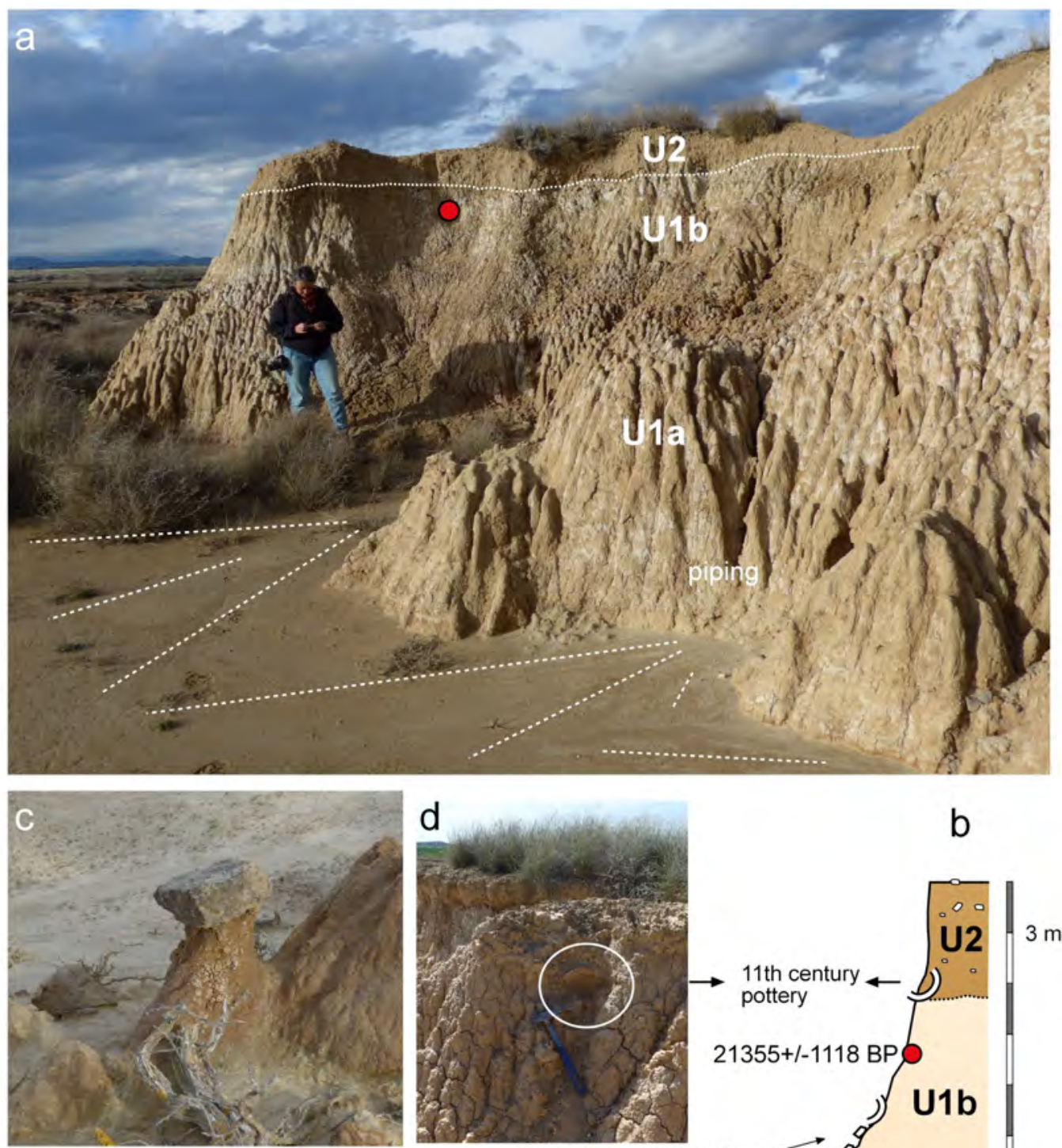

b
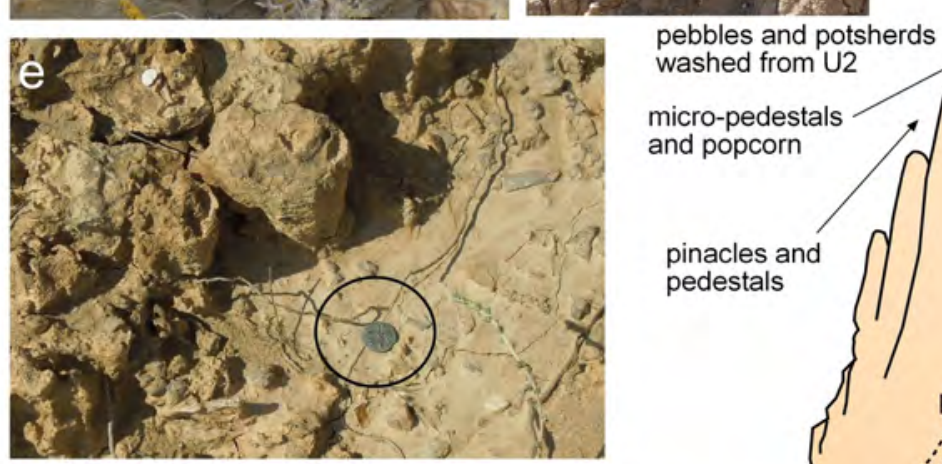

pebbles and potsh
washed from U2

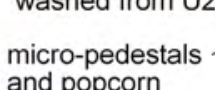

and popcorn
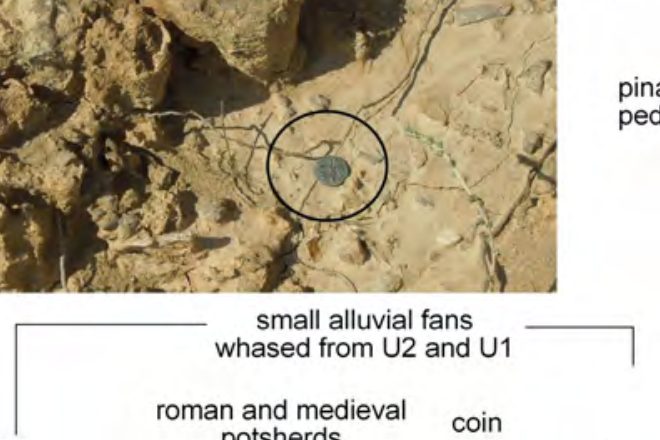

small alluvial fans whased from $\mathrm{U} 2$ and $\mathrm{U} 1$

roman and medieval

potsherds coin

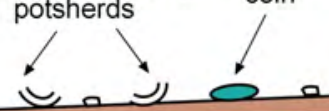

pedestal
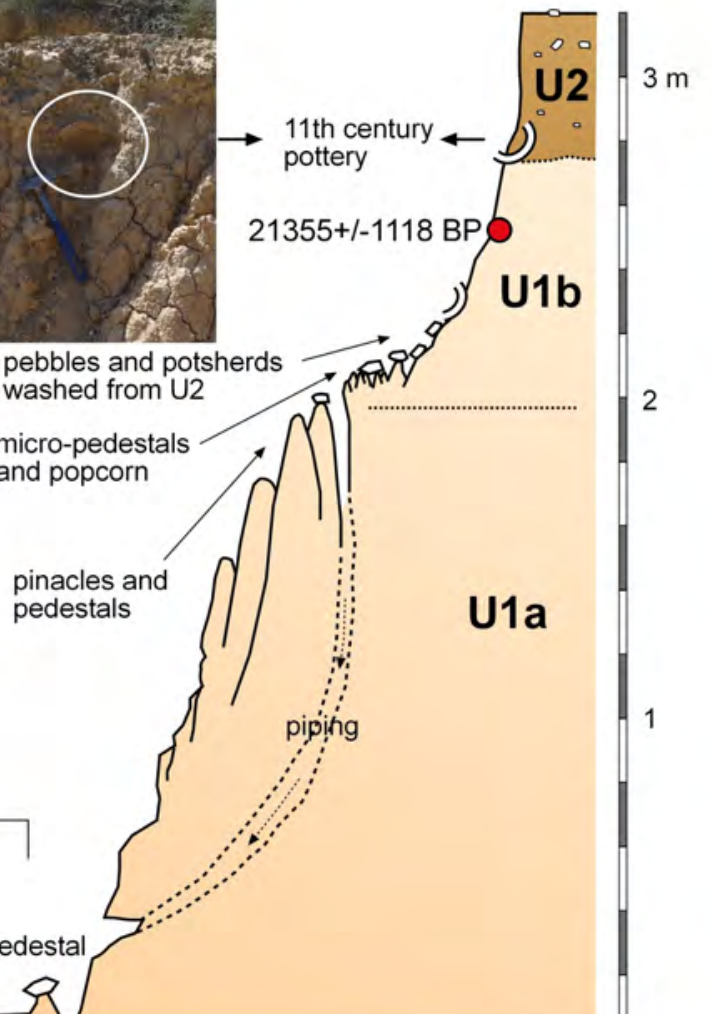


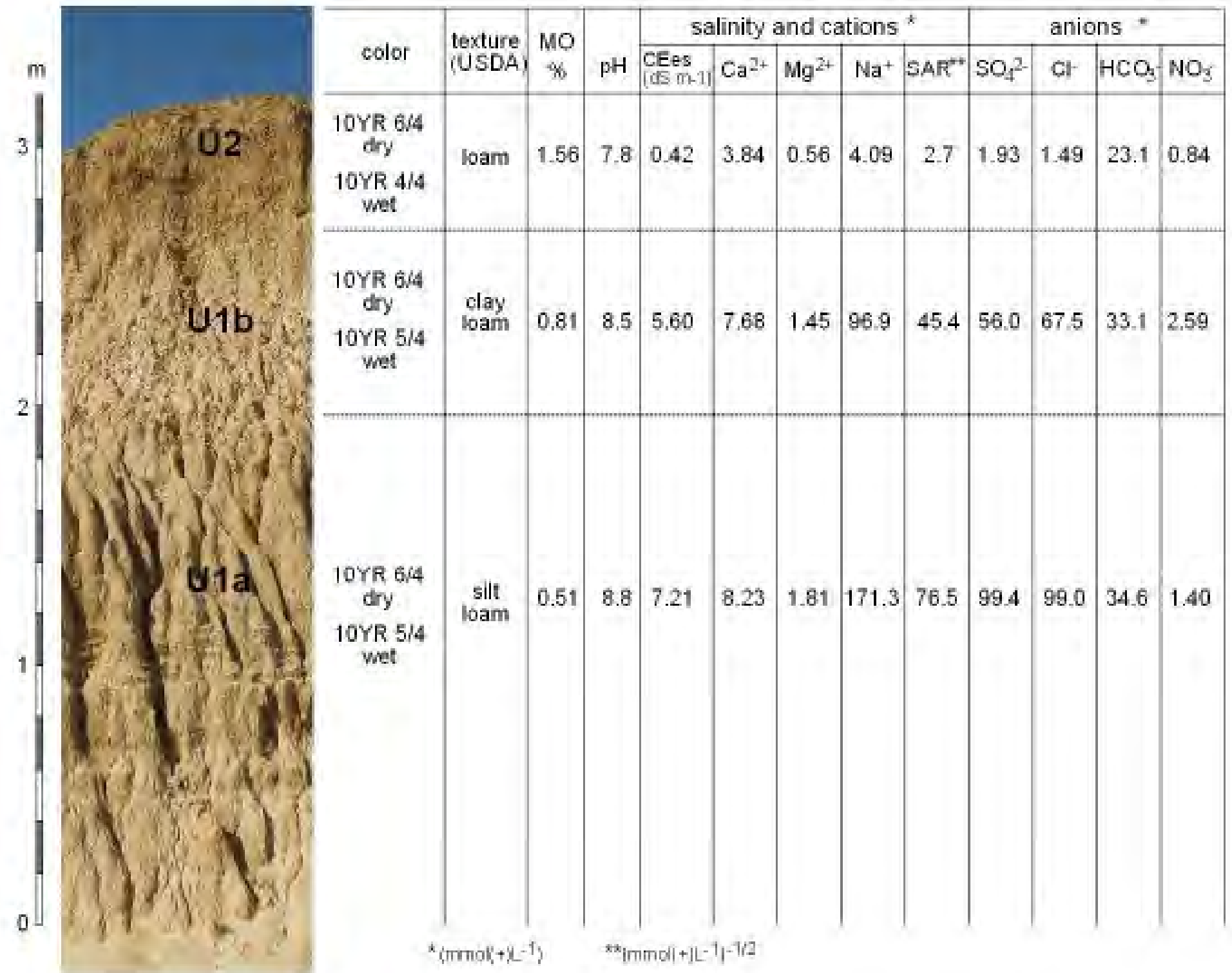




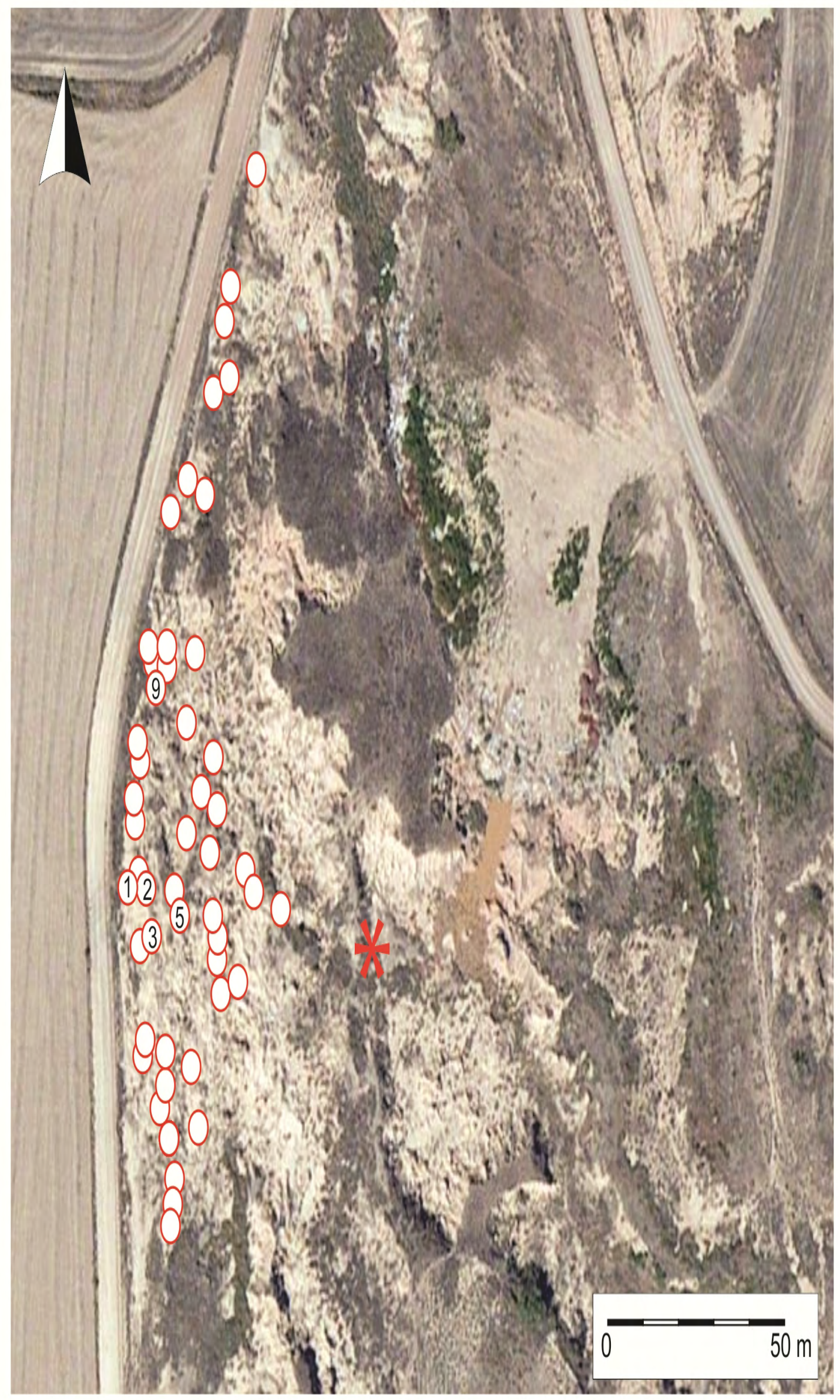



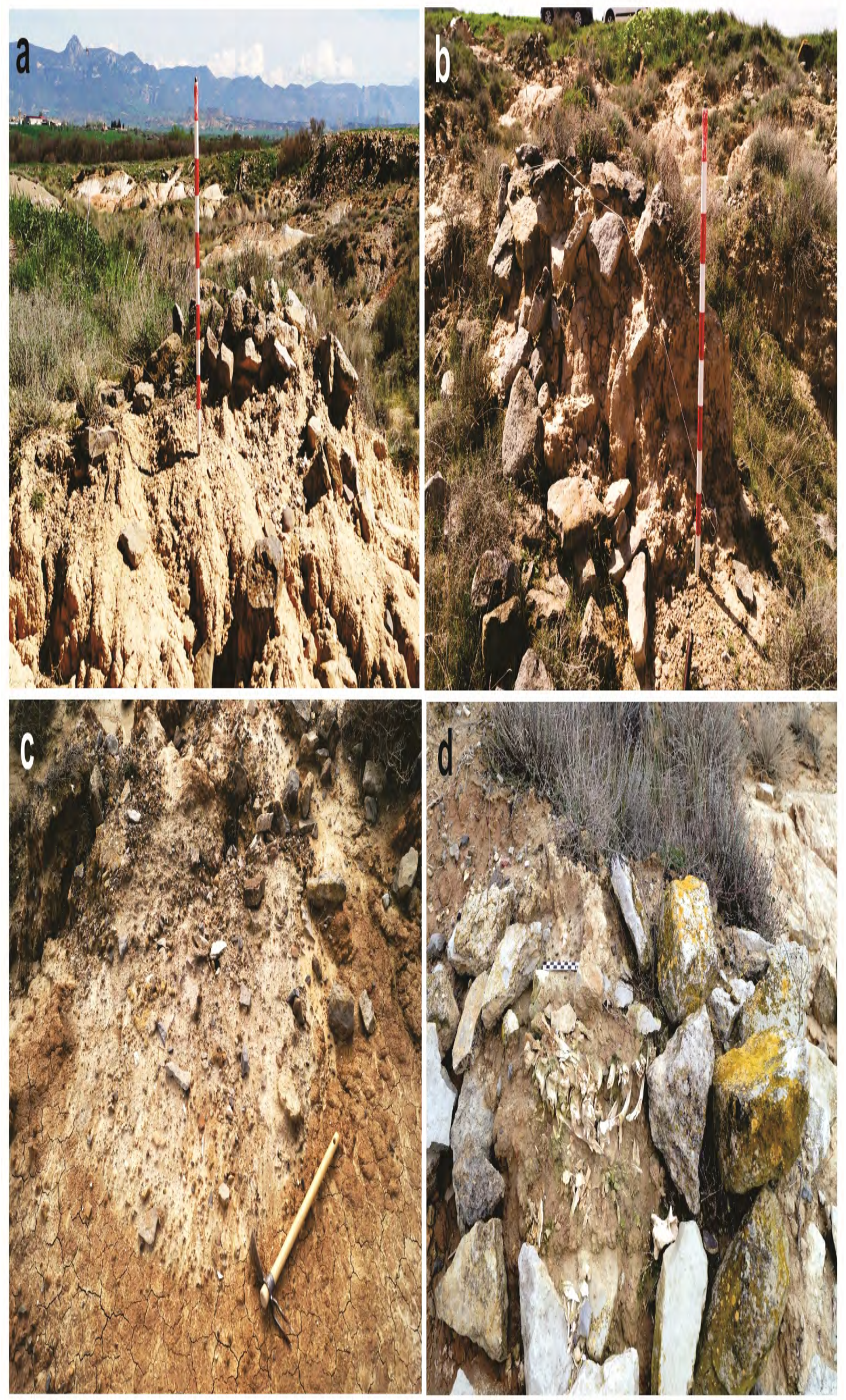
0 Fluvial sandy loam and clays

U1

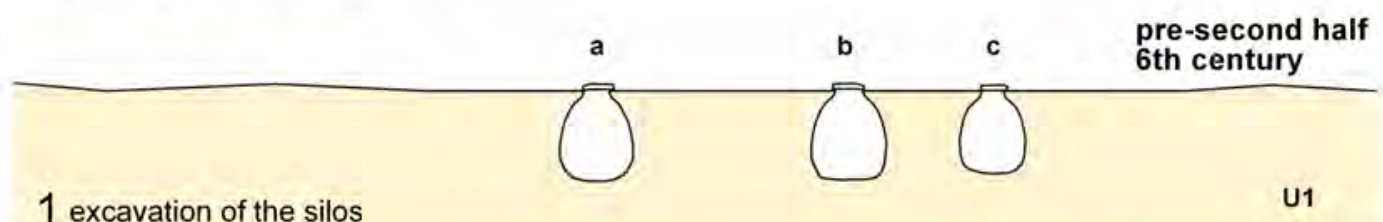

1 excavation of the silos

U1

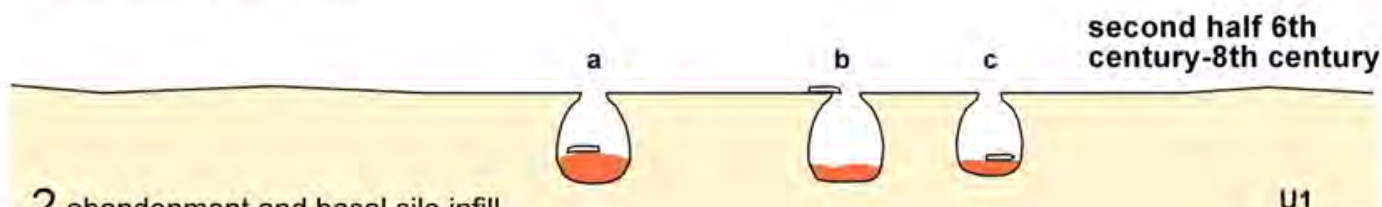

2 abandonment and basal silo infill

U1

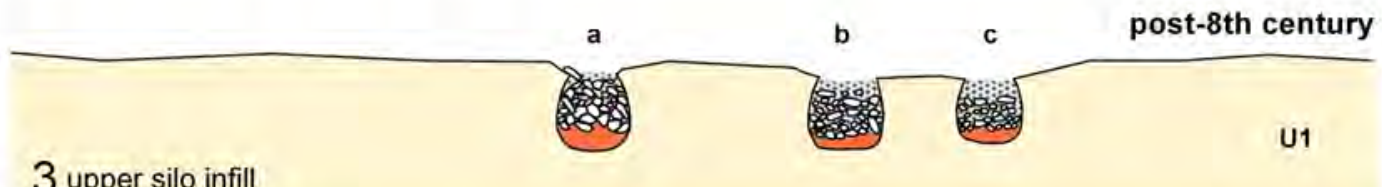

11-17th centuries

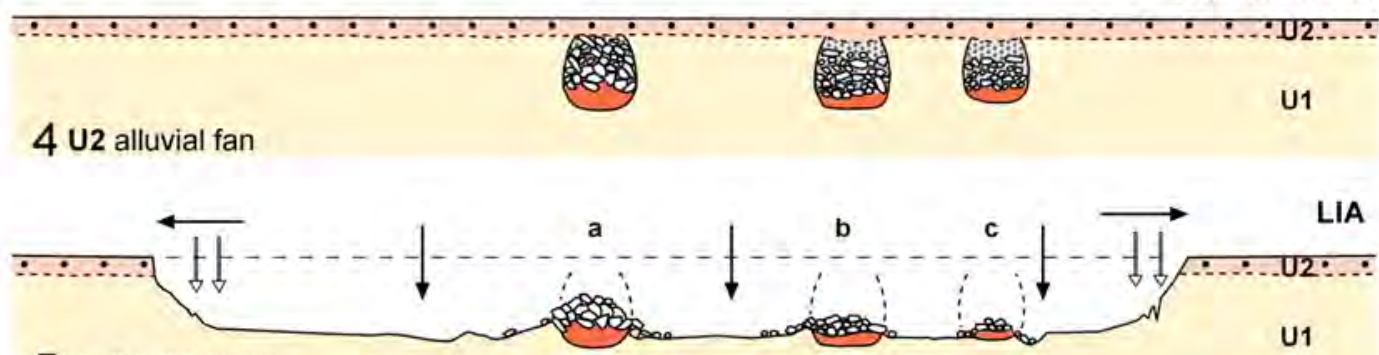

5 badland incision

LIA

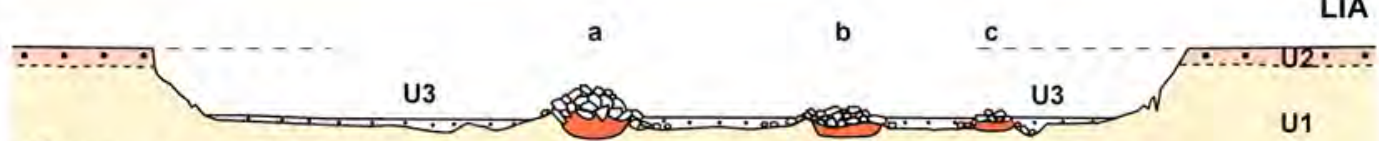

6 u3 badland infill

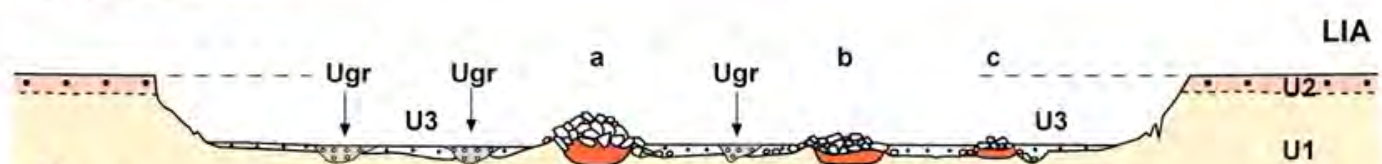

7 Ugr gravels event

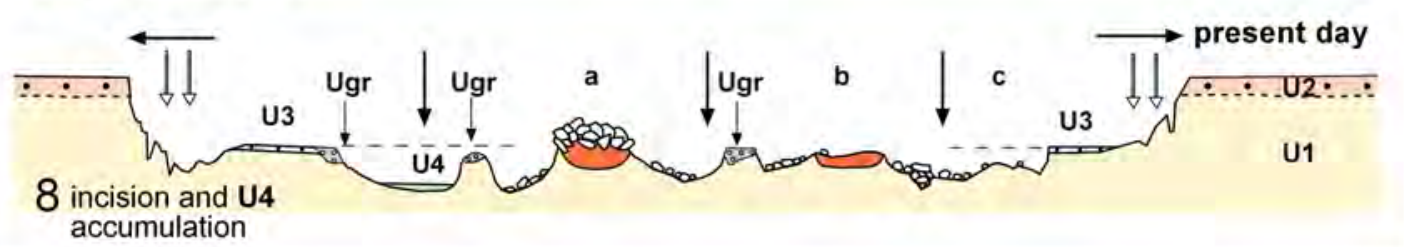

accumulation

U1 fluvial floodplain

-. U2 alluvial fan

U. U3 badland infill $\therefore:$ Ugr gravels event

$\mathbf{U} \mathbf{4}$ badland infill silo structures silo's basal infill

$\rightarrow$ lateral retreat

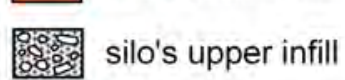

11 piping

stone mounds

$\downarrow$ incision 


\begin{tabular}{|c|c|c|c|c|c|c|}
\hline \multicolumn{7}{|c|}{ OSL Dating } \\
\hline $\begin{array}{l}\text { Laboratory } \\
\text { Code }\end{array}$ & $\begin{array}{l}\text { Equivalent } \\
\text { dose (Gy) }\end{array}$ & \multicolumn{2}{|c|}{$\begin{array}{l}\text { Annual Dose } \\
\text { (mGy/año) }\end{array}$} & \multicolumn{2}{|c|}{ Years B.P. } & Location \\
\hline $\begin{array}{c}\text { MAD- } \\
\text { 5442bisBIN }\end{array}$ & 58.94 & \multicolumn{2}{|l|}{2.76} & \multicolumn{2}{|c|}{$21355 \pm 1118$} & LUPI-1 \\
\hline \multicolumn{7}{|c|}{ Radiocarbon datings } \\
\hline Sample & $\begin{array}{l}\text { Laboratory } \\
\text { code }\end{array}$ & C14 BP & & $1 \sigma$ & Cal AD 2o & Location \\
\hline Pedregales 1 & GrA-60640 & $1520 \pm 30 \mathrm{BP}$ & 53 & cal & $\begin{array}{c}526-609 \text { cal } \\
\text { AD }\end{array}$ & Structure 1 \\
\hline Pedregales 2 & GrA-60642 & $1300 \pm 30 \mathrm{BP}$ & 66 & cal & $\begin{array}{c}660730 \text { cal } \\
\text { AD }\end{array}$ & Structure 2 \\
\hline
\end{tabular}

Table 1. OSL and radiocarbon datings. 